\title{
KAFKA KONTRA MESJANIZM. KRYZYS MITYCZNEGO UZASADNIENIA PRAWA W KULTURZE EUROPEJSKIEJ
}

\author{
Abstract \\ KAFKA VERSUS MESSIANISM. THE CRISIS OF THE MYTHICAL \\ JUSTIFICATION OF LAW IN EUROPEAN CULTURE
}

The essay is centered around the political and historical interpretation of Franz Kafka's short story In the Penal Colony. The theoretical context includes Claude Levi-Strauss's comments on "cold" societies (trying to deny history) and "hot" societies (trying to internalize the history). The aim of the interpretation is to create a simplified model of the shifts taking place in European culture in terms of the relations between myth, law, and (a specific kind of) messianism and to capture the differences between the pre-modern and the modern approach to the myth as a kind of fabricated imitation of eternity. The methodological tool used to this end includes a critical and hermeneutical interpretation involving reading literature in the light of historical processes, and historical processes in the light of literature. The disintegration of the torture apparatus in the Kafka's story can be decoded as the transition from "cold" to "hot" society, i.e. as an entry into enlightened modernity, where the awareness of the fact that transcendence is something fabricated becomes universal. This reduces the politics practised in modern, illuminated, and liberal societies (which conceal their own mythical nature under a veneer of science and democracy) to the need to choose between cynicism and fanaticism: between the cynical politics of ressentiment, which involves fabrication of emotions that drive the social machine, and the politics of virtue revived by desperate messianism that can no longer believe in its own truth.

SŁOWA KLUCZE: Franz Kafka, Platon, Lévi Strauss, Bateson, antropologia strukturalistyczna, mesjanizm, mit, prawo, polityka resentymentu, polityka cnoty

KEY WORDS: Franz Kafka, Platon, Lévi-Strauss, Bateson, structural anthropology, messianism, the myth, the law, politics of ressentiment, politics of virtue 
Zawrotna formuła z Timajosa głosi, że „czas jest ruchomym obrazem wieczności”' A gdyby tak zestawić ją z charakterystyką zimnych i gorących społeczeństw z Myśli nieoswojonej Claude'a Lévi-Straussa?

Wszystkie społeczności, powiada Lévi-Strauss, „tkwią w historii i podlegają zmianie", ale ze swoją nieuniknioną historycznością mogą sobie radzić na dwa różne sposoby. Społeczeństwami zimnymi są te, „które przez wytwarzane przez siebie instytucje próbują w sposób quasi-automatyczny zacierać skutki, jakie wywierać mogłyby czynniki historyczne na ich równowagę i ciągłość”, i usiłują „z niedocenianą przez nas zręcznością w miarę możliwości utrwalić stany, które uważają za »pierwsze« w swym rozwoju"4. Wewnętrzny ruch mający na celu brak ruchu; aktywne dążenie do niezmienności, uparte imitowanie pierwotności - wszystko to odróżnia zimne społeczeństwa od gorących. Te ostatnie „śmiało interioryzują stawanie się historyczne, by uczynić z niego motor swojego rozwoju", a zatem nie tylko zmieniają się, ale również nie udają same przed sobą, że trwają w stanie pierwotnym.

Terminologia wybrana przez Lévi-Straussa jest intuicyjnie zrozumiała: społeczeństwa historycznie unieruchomione są zimne, a historycznie ruchliwe - gorące. Rzuca się jednak w oczy, że nieruchomość społeczeństw zimnych jest zdaniem Lévi-Straussa pozorna. Ich ruch jest intensywny, ale dokonuje się w miejscu. Są jak koła pojazdu, który zagrzebał się w piasku, albo jak człowiek idący pod prąd na ruchomych schodach. Można stąd wnioskować, że społeczeństwa zimne są bardziej wewnętrznie rozgrzane od społeczeństw, które zdecydowały się popłynąć z prądem historii. Zimne społeczeństwa w istocie aż wrą od wewnętrznego napięcia, jakby nieustannie groziło im, że w końcu wybuchną i rozpadną się.

Czy starożytni Grecy - powiedzmy, w czasach Platona - byli społeczeństwem zimnym (to znaczy introwertycznie rozpalonym) czy gorącym (to znaczy ekstrawertycznie schłodzonym)? To dobre pytanie, bo naprowadza na trop elementarnej względności obu określeń. Platon pisze w Timajosie o greckiej „,młodej duszy”. „Nie ma starca między Hellenami”. Młoda dusza to dusza gorąca. Grecka ciekawość świata i aprobata dla politycznych innowacji, a więc cechy charakteryzujące społeczeństwa gorące, kontrastują z egipskim, zimnym przywiązaniem do starych form. Jednocześnie w porównaniu z nami Grecy, ze swoją cyrkuralną koncepcją dziejów, byli zimni. Czy jednak w samym pojęciu struktury u Lévi-Straussa również nie ma czegoś zimnego, poskramiającego i wychładzającego wszelką pracę historii? Synchronia jest zimna, a diachronia gorąca, obie pozostają jednak sprzęgnięte, jakby były skrzyżowaniem lodówki (wymagającej gorącego silnika) i samochodu (wymagającego systemu chłodzenia).

Ale nie dla takich rozważań zestawiam formułę platońską z lévi-straussowską. Chodzi mi raczej o obraz ewokowany przez te obie formuły. Jeśli je umiejętnie zlepić, uzyskać z nich można metaforę ontologiczną: wizję uczasowionego bytu jako pochyłego

1 Tim 37d.

2 C. Lévi-Strauss, Myśl nieoswojona, thum. A. Zajączkowski. Warszawa 2001, s. 311.

3 Tamże, s. 310.

${ }^{4}$ Tamże, s. 310.

5 Tamże, s. 310.

${ }^{6} \operatorname{Tim} 22 \mathrm{~b}$. 
i śliskiego. Wyobrazić sobie można mianowicie, że istnienie jest pochyłą gładką płaszczyzną, po której toczy się w dół nieskończenie ciężka kula historii (ciężkość jest tutaj synonimem bezwładności materii albo śmierci - to zarazem ananke albo fatum, coś wcześniejszego od patriarchalnych bogów i prawdopodobnie od nich trwalszego). Niewidzialnym Syzyfem, który wciąż na nowo powstrzymać próbuje upadek kuli i wtoczyć ją po równi pochyłej bytu na sam jego szczyt, jest tragiczny bohater historii, który reprezentuje tutaj czynnik duchowy: duszę, wolę, rozum, podmiotowość (mniejsza w tej chwili o różnice między nimi). Szczyt - równie niewidzialny jak bohater dziejów i prawdopodobnie równie fikcyjny, być może nawet geometrycznie niemożliwy reprezentuje zaś na tym obrazku wieczność: to hipotetyczne miejsce, w którym kula utrzymać mogłaby się w równowadze, przestając wciąż na nowo osuwać się w śmierć. Oto ,podwójne wiązanie"7 historii: trzeba zmienić wszystko, aby nie zmieniło się nic. Sprzeczność tę można ująć też w formule: aby zachować życie, trzeba je stracić. Trzeba poświęcić siebie (historycznego, czasowego, śmiertelnego), żeby siebie odzyskać (w wieczności) - chociaż przecież ten, kto siebie poświęci, nie będzie już mógł niczego odzyskać. Kto jednak nie zechce podlegać zmianie, tego zmiana i tak z sobą porwie. Chętnych los prowadzi, niechętnych - wlecze. Opowieści, które wplątują społeczeństwa w tego rodzaju historyczne ,podwójne wiązanie”, sprzeczny wewnętrznie imperatyw, nazywać można mitami. „Celem mitu - pisze Lévi-Strauss - jest dostarczenie logicznego modelu rozwiązywania sprzeczności (co jest zadaniem niewykonalnym)"».

Szczyt góry: paradoksalny stan równowagi, moment wieczności - jest bijącym sercem mitu, jego rajem utraconym i ziemią obiecaną. Jest miejscem, z którego społeczeństwa, jak wierzą, upadają w czas i do którego próbują powrócić każdym swoim działaniem. Na pierwszy rzut oka mogą to być działania zupełnie przyziemne i doraźne. A jednak - kontekstem nadającym im sens, choć zwykle ukrytym pod codzienną krzątaniną, jest właśnie moment wieczności artykułowany autorytatywnie przez mit i wszelkie inne pełniące mityczne funkcje opowieści (takie jak, na przykład, współczesne ideologie polityczne, podpowiada Lévi-Strauss), o ile czynne są w nich eternalizujące mitemy:

Dla homo politicus i tych, co mu dają posłuch, Rewolucja Francuska jest rzeczywistością $\mathrm{z}$ innego porządku; jest sekwencją wydarzeń minionych, a zarazem wyposażonym w trwałą skuteczność (podkr. moje - P.G.) schematem, pozwalającym intepretować strukturę społeczną dzisiejszej Francji i występujące w niej antagonizmy oraz przewidywać zarysy przyszłej ewolucji. Michelet, myśliciel polityczny, a zarazem historyk, wyraża się tak: „Tego dnia wszystko było możliwe... Przyszłość była obecna... to znaczy nie było już czasu, lecz błysk wieczności”"

7 Bateson wiąże koncepcję ,,double bind” z koncepcją , deutero-lerning” (Bateson 1987, s. 201), to znaczy uczenia się uczenia polegającego na zdolności do oduczania się wyuczyonych nawyków. Deutero-nauczanie to właściwie diachronicznie ujęta kultura (w sensie: paideia, wychowanie). $Z$ tego punktu widzenia kultura polega na wyrabianiu w sobie nawyków po to, aby je łamać; jest habitusem odrzucania habitusu, jej imperatyw brzmi: rozkazuję ci mnie nie słuchać. Por. G. Bateson, Steps to an Ecology of Mind. Collected Essays in Antropology, Psychiatry, Evolution, and Epistemology, Northway, New Yersey-London 1987, s. 199-203.

8 C. Lévi-Strauss, Antropologia strukturalna, tłum. K. Pomian, Warszawa 2000, s. 207.

9 Tamże, s. 188. 
Jeśli mit jest opowieścią wyznaczającą miejsce wieczności, wskazującą je gestem wyciągniętej ręki, jaką żeglarz pokazuje ląd na horyzoncie, to pod względem potencjalnej skuteczności tego gestu nie ma różnicy między społeczeństwami zimnymi i gorącymi. Starsze nie oznacza tu lepsze. Lévi-Strauss podkreśla, że żadna wersja mitu nie jest bardziej autentyczna czy źródłowa niż inne:

Proponujemy bowiem, by określić każdy mit przez zbiór wszystkich jego wersji. Inaczej mówiąc, mit pozostaje mitem tak długo, jak długo jest ujmowany jako mit. Nasza interpretacja mitu Edypa dobrze ilustruje tę zasadę, gdyż może się ona oprzeć na Freudowskim sformułowaniu mitu i niewątpliwie stosuje się do niego [...] Bez wahania umieścimy więc Freuda za Sofoklesem wśród naszych źródeł mitu Edypa ${ }^{10}$.

Jakże wyzywająco anarchistyczna, niemal nieograniczona wolność interpretacyjna w dziedzinie mitu wyziera zza tych słów, choćby i wbrew intencjom ich autora! Lévi-Strauss zaprowadza wśród mitów demokrację - a to znaczy, że musi być gotowy do królobójstwa. Czy James Joyce nie zostaje w ten sposób zrównany z Homerem, czy interpretacja mitu nie zostaje zrównana z mitem samym? Wszelka metaopowieść, wszelkie teoretyzowanie na temat mitu odgrywać może rolę potencjalnie analogiczną do mitu, polegającą na krystalizowaniu życia społecznego ${ }^{11}$. Czy w końcu sam mit nie jest swoją własną interpretacją, czy nie polega na wypracowywaniu wciąż nowych wariantów tego samego tematu - powtarzaniu tych samych motywów, ale zawsze trochę inaczej - dzięki czemu ,pojawia się teoretycznie nieskończona ilość warstw, z których każda różni się nieco od poprzedniej"? ${ }^{12}$

Lévi-Strauss ma w sobie co prawda wiele $\mathrm{z}$ naukowca biurokraty (co znów nie tak rzadkie wśród demokratów połowy XX wieku). Zdumiewające są jego fantazje, doprawdy kafkowskie $\mathrm{z}$ ducha, o potrzebie finansowania przez rząd olbrzymich ruchomych archiwów mitograficznych, gromadzących wielkie tablice z zapisanymi na nich wariantami mitów pochodzącymi z wszystkich kultur świata; archiwów, które stanowiłyby coś w rodzaju analogowych etnologicznych maszyn liczących a zarazem punkt centralny całego nowego działu administracji państwowej ${ }^{13}$.

10 Tamże, s. 195.

11 „Mit jest bytem słownym, który zajmuje w dziedzinie mowy jednostkowej miejsce, jakie zajmuje kryształ w świecie materii fizycznej. Jego pozycja względem języka i mowy jednostkowej jest bowiem analogiczna do pozycji kryształu, bytu pośredniego między statystycznym skupiskiem molekuł, a samą strukturą molekularną". Tamże, s. 207.

12 Tamże, s. 207. Co prawda kombinatoryka, za pomocą której dochodzi do wyłaniania się tych kolejnych warstw, bardzo zajmująca Lévi-Straussa, poszukującego matematycznego równania mitu niby jakiegoś kamienia filozoficznego człowieczeństwa, wydaje mi się zupełnym nieporozumieniem (o czym piszę w dalszej części tekstu) - ale nieporozumieniem interesującym jako przejaw „mitu indywidualnego” Lévi-Straussa; mitu, który dzielił jednak zapewne z większością współczesnych mu ludzi Zachodu.

${ }^{13}$ „Teksty mityczne są niezmiernie obfite. Ich rozczłonkowanie na jednostki konstytutywne wymaga pracy zespołowej i personelu technicznego. Wariant średnich rozmiarów dostarcza wielu setek kart. Aby odkryć najlepszy układ tych kart w kolumny i wiersze, trzeba mieć pionowe klasery o rozmiarach ok. $2 \mathrm{~m}$ x 1,50 m, zaopatrzone w przegrody, w których można dowolnie przemieszczać i przesuwać karty. Z chwilą, gdy usiłuje się budować modele trójwymiarowe, aby porównać 
Nie zmienia to faktu, że jak zapewne każdy archiwista, Lévi-Strauss pod pewnym względem pozostaje anarchistą, trzyma pistolet w biurku. Wierzy mianowicie, że mityczny duch nigdy nie przestał się wylewać, że nie tylko prehistoryczni zbieracze i myśliwi, nie tylko Indianie z lasów Amazonii i starożytni Grecy, ale również my, obywatele XXI wieku, wciąż przydawać możemy naszym opowieściom mityczną skuteczność.

Choćby i z tym zastrzeżeniem, zgłaszanym przez samozwańczych kapłanów a zarazem, co charakterystyczne, prywatnych przedsiębiorców współczesnego mitu, psychoanalityków, że mit może być dzisiaj tylko - według Lévi-Straussowskiej formuły podchwyconej następnie przez Jacqes'a Lacana - „indywidualnym mitem neurotyka" ${ }^{14}$. Sformułowanie to streszcza według Lévi-Straussa seksualną filozofię religii (czy też religijną filozofię seksu) Zygmunta Freuda ${ }^{15}$. W warunkach nowoczesności, a więc, mówiąc językiem Lévi-Straussa - w społeczeństwach ,gorących”, czyli - dopowiedzieć można - społeczeństwach stanów gazowych, a w najlepszym razie płynnych, a nie stałych; w społeczeństwach, w których atomy krążą swobodnie i nie są związane w bryły - mity mają charakter autorski. Są dziełami zatomizowanych jednostek, wyobcowanych artystów - chociaż niezupełnie są dziełami świadomymi, lecz raczej czymś podobnym do snów na jawie ${ }^{16}$, niekiedy przejmowanych przez innych i przybierających wymiary epidemii.

Myśl o indywidualistycznym charakterze neomitów, którą Lévi-Strauss przypisuje Freudowi, stanowi zresztą starszy motyw, wywodzący się z czasów romantyzmu. Odnaleźć go można już w Filozofii sztuki Schellinga, który mitologię starożytnych porównuje do układu planetarnego, a mity nowoczesne do meteorów i komet - rozproszonych jeszcze zapowiedzi mitologii, która spajać będzie przyszłe, zjednoczone społeczeństwo (być może syntezę społeczeństwa zimnego i gorącego). Notabene, pierwszą z mitycznych komet nowoczesności - co zaskakujące - jest według Schellinga Boska Komedia ${ }^{17}$.

wiele wariantów, trzeba mieć tyle klaserów, ile jest wariantów, oraz swobodną przestrzeń, aby przemieszczać je i rozkładać. Wreszcie, jeśli system odniesienia odwołuje się do więcej niż trzech wymiarów, [...] trzeba korzystać z kart performowanych i mechanografii”. Tamże, s. 207. Z perspektywy wieku XXI aż za łatwa jest uwaga, że wszystko, o czym tu pisze Lévi-Strauss, nie wymagałoby dzisiaj wielkich pomieszczeń i zastępów ludzi, wystarczyłby najmniejszy z komputerów osobistych (aczkolwiek nawet i bez komputera można się domyślić, że wszystkie te skomplikowane zabiegi doprowadzić mogłyby tylko do udowodnienia tego, co Strauss założył już na samym począt$\mathrm{ku}$ ). Ale nie o to przecież chodzi. Lévi-Straussowi marzy się stworzenie wielkiego urzędu ds. mitu, strukturalistycznej instytucji o wymiarze mitycznym, która stałaby się istotnym czynnikiem polityki teoretycznej, przynajmniej w ramach świata akademickiego, a nie o przeprowadzenie serii rachunków i zamknięcie sprawy.

${ }_{14}$ J. Lacan, Mit indywidualny neurotyka albo poezja i prawda w nerwicy, thum.T Gajda, J. Kotara, J. Waga, Warszawa 2015.

${ }^{15}$ Levi-Strauss pisze o ,indywidualnym micie, na którym polega nerwica”. C. Lévi-Strauss, Myśl nieoswojona, s. 206.

${ }^{16}$ Czymś jak „Sen śmiesznego człowieka”.

17 „Powszechny duch świata, który niejako konkretnie ustanowił nieskończoność historii w przyrodzie i systemie świata, ustalił to samo przeciwieństwo, przeciwieństwo dawnego i nowego czasu, 
Przez słowa Lévi-Straussa, poza romantyczno-zielonoświątkową wiarą w niewygasłą płodność mitycznego ducha, przemawia też jednak jakiś fatalizm: pewność ponadhistorycznej potęgi mitu, zdolnej przeniknąć i podporządkować sobie wszystkie swoje warianty, nawet te, które przedstawiają się jako naukowe, które wołają: „Mehr licht!"18. Dzieje się tak nie w przypadku Freuda, lecz także samego Lévi-Straussa którego przecież również można i należy remityzować, tak jak on, nie bez pewnej złośliwości, remityzował Freudowską psychoanalizę. Remityzować znaczy jednak tylko: odkrywać neurozę pod teorematem (znak pod pojęciem) - zrozumieć, w jaki sposób pojęcia chytrze instrumentalizowane są przez powracające obsesyjnie obrazy zarażające „błyskiem wieczności”.

Zachęcony antropologicznym anarchizmem, wylewającym się zza naukowej fasady strukturalizmu, sięgnę po kolejną młodą wersję mitu, tym razem mitu faustowskiego. W operze Ferruccio Busoniego, napisanej w pierwszych dekadach XX wieku, Faust, wybierając sobie diabła na sługę, kieruje się jednym tylko kryterium - a mianowicie kryterium prędkości. Po odrzuceniu ofert ze strony demonów wolniejszych, Faust decyduje się w końcu na Mefistofelesa, który reklamuje się jako „szybki niczym człowiecza myśl" "'. Skąd ta obsesja szybkości? Inaczej - dlaczego człowiecza myśl pragnęła być tak szybka, jak to tylko możliwe, szybka jak najszybszy z demonów? Dlaczego intelektualista Faust przejść do czynu może tylko za pomocą demonicznego przyspieszenia? Tłumaczy to metafora pochyłego bytu: jeśli czas jest ruchomym obrazem wieczności, im szybszy jest ten ruch, tym bardziej zbliża się do wieczności, tym lepiej ją imituje. Nie ma przy tym znaczenia, czy to ruch ucieczki „do przodu” czy „do tyłu” - czy jest gorący czy zimny, czy stara się jak najszybciej wymazywać zmiany, czy przeciwnie, potęgować je - za każdym razem to ruch, który próbuje uchylić się przez niepożądanymi konsekwencjami zmian (obsuwania się po stromiźnie bytu w śmierć). Wyprzedzając zmianę, reagując jak najszybciej na wszystko to, co życiu zagraża, można najefektywniej - choć zawsze tylko doraźnie, ma „mgnienie oka”, czyli czas, kiedy zwierają się powieki i śmierci nie widać utrzymać przy życiu, uchylić od strzałów ze wszystkich pistoletów natury, jak Neo z filmu Matrix.

Nad tym zastanawiająco popularnym dziełem rodzeństwa Wachowskich warto się na chwilę zatrzymać. Matrix również stanowi zapewne wersję jakiegoś mitu - ale

w systemie planetarnym i świecie komet. Ludzie antyku są planetami świata sztuki, ograniczonymi do niewielu indywiduów, które zarazem są gatunkami i przy najbardziej swobodnym ruchu nie oddalają się w najmniejszej mierze od tożsamości. [...] Do komet przynależy przestrzeń bez granic [...] W taki sposób - by rzecz pokazać na wyraźnym przykładzie najwybitniejszego indywiduum nowoczesnego świata - z barbarzyństwa i jeszcze barbarzyńskiej uczoności swego czasu, okrucieństw historii, których sam doświadczył, jak również z tworzywa istniejącej hierarchii stworzył sobie Dante własną mitologię, a wraz z nią swój boski poemat”. F.W.J. Schelling, Filozofia sztuki, thum. K. Krzemieniowa,Warszawa 1983, s. 117-118.

18 J. Lacan, Mit indywidualny neurotyka..., s. 43.

19 „Faust, ich bin geschwind als wie des Menschen Gedanke”. F. Busoni, Doktor Faust. Libretto, 1925, http://opera.stanford.edu/Busoni/DrFaust/libretto.html (Monday, 08-Dec-2003 21:50:15 PST) [dostęp: 1.06.2017]. 
jakiego? Czy to mit o powrocie do rajskiego ogrodu, o ucieczce z upadłej, późnej nowoczesności do cyberpunkowego obozu harcerskiego zwanego Syjonem, gdzie maszyny sterowane są ręcznie, gdzie myśl i mięsień człowieka panują nad cybernetycznymi urządzeniami? Wbrew pozorom Matrix nie jest, jak sądzę, bajką eskapistycznie technofobiczną. Konstruuje raczej mit nowego hipermaszynowego mesjasza, który potrafi nagiąć reguły rzeczywistości i dlatego zwyciężyć może z maszynami w pojedynku na szybkość. Maszyny muszą pracować zgodnie z regułami, ludzka myśl, szybka jak Mefistofeles, potrafi jednak łamać reguły - wprowadzać stan wyjątkowy - dlatego zawieszający reguły filmowy neomesjasz wyprzedza w końcu maszyny ${ }^{20}$.

Odnieść to można również do „zimnych” społeczeństw u Lévi-Straussa: im szybciej -,,quasi-automatycznie" - zacierane w nich będą wszelkie skutki wpływu czynników historycznych na równowagę i ciągłość instytucji, tym silniejsza będzie ich „skuteczność symboliczna”, według formuły zaczerpniętej z eseju zamieszczonego w Antropologii strukturalnej ${ }^{21}$, budującego wielką analogię między mitami i rytuałami „zimnych” ludów a psychoanalizą.

O ile Matrix jest raczej bezkrytyczną, popkulturową reklamą pewnego typu nowo-mesjanistycznej ideologii przyspieszenia, o tyle krytyczną wizję mechanizmu powstawania wszelkiej skuteczności symbolicznej - wizję, która demaskuje mesjanizm radykalniej chyba niż pisma Nietzschego ${ }^{22}$, mającego w gruncie rzeczy ambiwalentny stosunek do religii w ogóle, a do mesjanizmu w szczególności - znaleźć można w Kolonii karnej Franza Kafki.

Kafkowska wizja jest przy tym obosieczna - przypuszcza atak zarazem na mesjanizm i na liberalną krytykę mesjanizmu. W opowiadaniu tym przeprowadzona zostaje na naszych oczach demonstracja oddziaływania podwójnego wiązania mitu obie możliwe drogi (trwanie i zmiana) okazują się fałszywe.

Można podejrzewać, że Kafka - razem z Eurypidesem, Friedrichem Nietzschem i Samuelem Beckettem (tę listę można rozszerzać) - należy do tej części światowej literatury, w której dochodzi do głosu wewnętrzny kryzys mitu. Możliwe zresztą, że świecka literatura albo jeszcze szerzej: sztuka jako taka - bo przecież, żeby traktować ją jako sztukę, już trzeba ją do pewnego stopnia zeświecczyć - jest każdorazowo świadectwem agonii (pewnego) mitu; być może warstwa estetyczna literatury czerpie siłę z rozkładania się jej warstwy mitologicznej, jak mech i huby, które rodzą się na obumarłych drzewach, zwiększając leśną bioróżnorodność. Ale Kolonia karna nie tylko wyrasta $\mathrm{z}$ agonii mitu, ale też wprost o tej agonii opowiada.

Oto podróżnik, badacz - pozbawiony przesądów człowiek Zachodu, być może etnograf, antropolog, naukowiec, w każdym razie liberał - pojawia się w kolonii

${ }^{20}$ Zastrzeżenie: w interpretacji tej uwzględniam jedynie pierwszą część trylogii, która traktowana może być jako skończone dzieło - jej sequele, a właściwie multiplikacje, rezultat oszałamiającego sukcesu komercyjnego odniesionego przez oryginał, wydają mi się intelektualnie dużo słabsze, a w każdym razie w takim stopniu powikłane, że wolę zrezygnować z przywoływania ich tutaj.

${ }^{21}$ C. Lévi-Strauss, Antropologia strukturalna, s. 173-183.

${ }^{22}$ Wspominam tu o nim choćby dlatego, że to on jest autorem współczesnego dzieła, którego sam tytuł jest synonimem nowoczesnego antymesjanizmu: Der Anti-Christ. Chrystus to greckie thumaczenie hebrajskiego słowa Mesjasz. 
karnej, na wyspie należącej do ponadczasowego „archipelagu Gułag” ludzkiej historiii $^{23}$. W obozie właśnie ma zostać wykonana makabryczna egzekucja. W jej szczegóły wtajemnicza badacza oficer, który przedstawia się jako zastępca i wyznawca zmarłego Starego Komendanta. Oficera, jako zastępcę, można by zapewne nazywać św. Piotrem Starego Komendanta, ale ze względu na swoje ambicje teoretyczne i strategiczne jest raczej jego Pawłem Apostołem. Spuźcizna Starego Komendanda - dowiaduje się podróżny - zdradzona została przez nowego komendanta, najwyraźniej niemrawego liberała, zniesmaczonego brutalnością dawnych stosunków (dość istotną rolę w charakterystyce nowego komendanta odgrywają „,damy”, które - gdy pominie się wątek płci kulturowej - uosabiają być może przede wszystkim jakąś niewyraźną, oblepiającą i odbierającą siły żywotne protoplazmę , dworskości”, dworskiej konwersacji i sentymentalnej moralności, podściółki, na której wyrastają grzyby oświecenia).

Centralnym elementem starego porządku jest, według świadectwa oficera, straszliwy aparat stworzony przez Starego Komendanta (tego, który „wszystko łączył w swojej osobie”, „był żołnierzem, sędzią, konstruktorem, chemikiem, rysownikiem" "24, a więc postacią poprzedzającą wszelki podział pracy), a mianowicie maszyna tak długo wypisująca na ciele skazańca sentencję wyroku, aż wykrwawi się on na śmierć, co trwało zawsze dwanaście godzin. Egzekucja za pomocą aparatu stanowiła kiedyś, jak mówi podróżnemu oficer, najważniejsze publiczne święto kolonii karnej. Było to święto sprawiedliwości, rytuał odnawiający więzy łączące wyspiarską społeczność, podstawowe narzędzie wychowawcze, jakie wspólnota ta miała do dyspozycji, najlepszy sposób socjalizowania jej członków. W słowach oficera pobrzmiewa w tym miejscu ewangeliczne „Pozwólcie dziateczkom przyjść do mnie!”25.

Komendant w swojej mądrości rozkazywał, aby przede wszystkim uwzględnić prośby dzieci; ja z racji mojego zawodu zawsze mogłem stać blisko; często też na prawym i lewym ramieniu piastowałem dwoje małych dzieci. Jakże nas przejmował wyraz zmiany na umęczonej twarzy, jakże mieniły się nasze policzki w blasku osiągniętej nareszcie, a już przemijającej sprawiedliwości! Cóż to były za czasy, kolego! ${ }^{26}$

Otóż były to czasy bezpośredniej obecności prawdy, czasy epifanii sprawiedliwości podczas publicznej egzekucji skazańców za pomocą aparatu. Obecnie jednak, w epoce nowej władzy, w czasach pozbawionego charyzmy nowego komendanta, egzekucje wykonywane są wstydliwie, pokątnie, w ukryciu. Nasze czasy, czasy nowego komendanta, to epoka, w której prawda objawia się jedynie pośrednio, można o niej tylko opowiadać, stała się mitem.

Najważnieszym momentem rytuału sprawiedliwości jest według oficera przemiana zachodząca w połowie czasu, w „szóstej godzinie” tortury.

${ }^{23}$ Uważam, że do obozu pracy porównać można każdą pracę wykonywaną pod przymusem, a taką jest każda praca w warunkach nierówności klasowej.

${ }^{24}$ F. Kafka, Proces, tłum. B. Schulz, Warszawa 1974, s. 193.

${ }_{25} \mathrm{Mk} 10,13$.

${ }^{26}$ F. Kafka, Kolonia karna, tłum J. Kydryński [w:] tenże, Opowieści i przypowieści, różni tłumacze, Warszawa, s. 204. 
Jakże spokojny staje się człowiek wtedy, około szóstej godziny! Najgłupszy przychodzi do rozumu. Zaczyna się to koło oczu: stąd się rozszerza. Widok ten mógłby skłonić do położenia się samemu pod bronę. Dalej nic się nie dzieje, człowiek zaczyna tylko odcyfrowywać pismo, otwiera usta, jak gdyby nasłuchiwał. Widział pan, że nie jest łatwo odczytać to pismo oczyma; ale nasz człowiek odcyfrowuje je swymi ranami. Jest to zresztą duża praca. Do jej wykonania potrzebuje on sześciu godzin ${ }^{27}$.

Maszyna pisze sentencję wyroku zawiłym pismem, które można odczytać tylko torturowanym ciałem, a nie oczami - to znaczy „odczytywać” można je tylko własnym życiem dążącym ku śmierci, a nie za pośrednictwem teorii. Jednak również w to, że arabeski wypisywane przez maszynę faktycznie układają się w sentencję wyroku, można jedynie uwierzyć - ci, którym podobno udaje się je w końcu odczytać, nie mogą już o tym poświadczyć, bo nie żyją. Nie wiadomo zatem, czy to, co aparat pisze na ciele skazańca, to w ogóle litery, czy pismo maszyny w ogóle należy do jakiegoś porządku znaków, czy ma związek z jakimkolwiek językiem. Wyspiarski system symboliczny nie ma źródła, jest symulakryczny, utrzymuje się mocą perswazji oraz imitacji.

Kafkowska „szósta godzina” mitu to moment, w którym torturowane ciało ciało wplecione śmiertelnie w ten symulowany porządek symboliczny, utrzymujący społeczność kolonii karnej w jedności - uwewnętrznia karę i godzi się ze światem. Dokładniej rzecz ujmując - w szóstej godzinie skazaniec dopiero się „,nawraca” - zwraca się cały w stronę zgody ze światem, godzi się dopiero z samą niezbędnością rozpoczęcia w sobie tego procesu zgody. Proces ten trwa, według słów oficera, dokładnie sześć godzin, czyli całą resztę czasu trwania egzekucji, aż do śmierci skazańca („Potem jednak brona przekłuwa go całkowicie i rzuca go do wykopu, gdzie $\mathrm{z}$ pluskiem pada na wodę z krwią i watą. Wówczas wymiar sprawiedliwości dobiegł końca, a my, ja i żołnierz, zagrzebujemy człowieka"28).

To znaczy - w ,szóstej godzinie” skazaniec przyjmuje na wiarę, że świat społeczny i rządzący nim porządek symboliczny jest sprawiedliwy. Zaczyna wreszcie wierzyć, że nad światem panuje prawo. Znowu uściślając: skazaniec uznaje za sprawiedliwy nie tyle sam świat, ile karę wyrywającą go z tego świata - stawiającą go poza światem regulowanym przez prawo, ale tym samym stawiającą mu przed oczami prawo samo - w którego realne istnienie wcześniej wątpił. Gotowy był przecież złamać przepisy prawa, mając samego siebie za ważniejszego od nich! Możliwe, że o ich istnieniu nawet nie miał pojęcia albo - co na jedno wychodzi - zapomniał, że istnieją - i nawet musiał zapomnieć, o ile żył w codzienności, bo codzienność to zapomnienie, że istnieje prawo; tak jak w Byciu i czasie Martina Heideggera Uneigentlichkeit to zapomnienie bycia ku śmierci, zapomnienie, że na najbardziej własną możliwość bycia można się zdecydować ${ }^{29}$. To właśnie o rozproszenie, o zapomnienie, o przebywanie w stanie codzienności, o Uneigentlichkeit tak naprawdę został oskarżony skazaniec - i tylko o to można zostać oskarżonym! Jedyne istotne oskarżenie to takie, które oskarża o to, że zapomniało się o tym, co istotne.

\footnotetext{
27 Tamże, s. 200.

28 Tamże, s. 200.

${ }^{29}$ M. Heidegger, Bycie i czas, tłum. B. Baran, Warszawa 1994, s. 475-476.
} 
A przecież bez reguł prawa skazaniec, nawet w stanie rozproszenia charakteryzującego codzienność, nie istniałby jako ten, za kogo się uważał. Tylko reguły prawa gwarantują wartość, jaką nadawał swoim słowom. Wszystkie słowa i gesty codzienności zawdzięczają bowiem swój ciężar chwili wieczności ogłaszanej czy wskazywanej przez mit (mit też jest przecież pewnym gestem - tak samo, jak gestem jest ułożenie skazańca w maszynie tortur).

Nie twierdzę, że gesty i słowa zawdzięczają owym enigmatycznym, istniejącym tylko na wiarę, w momencie egzekucji, regułom prawa swoje znaczenie - to znaczy, że zawdzięczają im treść, jaką komunikują. Istnieniu ich zawdzięczają jednak swoją, by tak rzec - pożywność, a co za tym idzie atrakcyjność, a więc to, że przyciągają uwagę (ciężar polega przecież na przyciąganiu). One sprawiają, że czegoś się w ogóle chce. Dzięki temu komunikacja dochodzi do skutku. Przesycona przez prawo - zasadę atrakcyjności - jest karmiącą skazańca papką światowości, którą musi przeżuwać, aby przeżyć wśród innych i sam z sobą. Kara stawia go poza tym światem reguł, odbiera światowość, ale daje zarazem pełną świadomość realności i ważności reguł, stanowi namacalny dowód ich obowiązywania.

Do szóstej godziny skazaniec jadł papkę ryżową podsuwaną mu przez oprawców (podkreślam ten wątek, bo bohaterowie Końcówki Becketta też jedzą ,pożywną papkę" ${ }^{30} \mathrm{i}$ ten wspólny motyw w tym kontekście nabiera podobnego znaczenia). Od momentu przemiany skazaniec przestaje być głodny, niczym najdoskonalsi katarowie, niczym Simone Weil w Londynie.

Dopiero około szóstej godziny nie znajduje już skazaniec przyjemności w jedzeniu. [...] Człowiek rzadko połyka ostatni kęs, obraca go tylko w ustach i wypluwa do wykopu ${ }^{31}$.

30 S. Beckett, Dzieła dramatyczne, tłum. A. Libera, Warszawa 1988, s. 196.

31 F. Kafka, Kolonia karna, s. 200. Nawiasem mówiąc, motyw wypluwania i wymiotowania, powtarzający się w opowiadaniu (wypluwana papka, wymiotujący skazaniec, maszyna wypluwająca skazańca, w końcu maszyna „wymiotująca” siebie samą - wyrzucająca z siebie własne wnętrzności), nasuwa skojarzenie z kolejnym wielkim (choć wprowadzonym mimochodem) rozróżnieniem Lévi-Straussa, oddzielających zasadniczo społeczeństwa zachodnie od innych, a mianowicie z opozycją kultur antropofagicznych i antropoemicznych: „Myślę o naszych praktykach sądowniczych i penitencjarnych. Badając je z zewnątrz, miałoby się ochotę przeciwstawić sobie dwa typy społeczeństw: społeczeństwa, które praktykują antropofagię, tzn. widzą w pochłanianiu niektórych jednostek władających groźnymi siłami jedyny sposób zneutralizowania tych sił, a nawet ich wykorzystania, i społeczeństwa, które, tak jak nasze, przyjęły coś, co można by nazwać »antropoemią« (od greckiego emein, wymiotować) i w obliczu tego samego problemu wybrały odwrotne rozwiązanie polegające na wyrzucaniu tych niebezpiecznych istot poza nawias organizmu społecznego, trzymając je w czasowym lub dożywotnim odosobnieniu bez kontaktu z ludźmi, w zakładach do tego przeznaczonych. W większości społeczeństw, zwanych przez nas pierwotnymi, ten zwyczaj wzbudziłby głębokie oburzenie: naznaczyłby nas w ich oczach piętnem takiego samego barbarzyństwa, jakie mielibyśmy chęć im przypisać z racji ich odpowiadających naszym zwyczajów". (C. Lévi-Strauss, Smutek tropików, Warszawa 2008, s. 408). Nawiasem mówiąc, mamy w tych uwagach do czynienia z dziełem Foucaulta in nuce. W kontekście niniejszych rozważań powiedzieć można, że cechą aparatu funkcjonującego w centrum życia społecznego (tj.w czasach Starego Komendanta, jeśli wierzyć oficerowi) jest antropofagia, a cechą aparatu usuniętego na margines (jak w czasach nowego komendanta) - antropoemia. 
Odtąd nie żyje już według świata, ale według ducha. W ten sposób niejako wyłączony zostaje, tak jak się wyłącza światło w pokoju, jego głód; roszczenie jego śmiertelnego organizmu, który wciąż odraczać chciałby chwilę śmierci (odraczać moment uświadomienia sobie, że prawo istnieje, korzystając zarazem z jego działania, to znaczy z atrakcyjności świata, z tego, że coś w ogóle na świecie jest pociągające). Ciało istnieje od tej pory już tylko jako instrument sprawiedliwości, jest ciałem anorganicznym, ciałem wyłączonych organów.

Aż do tego momentu - aż do ,szóstej godziny” - skazany nie wiedział, że w ogóle zapadł wyrok, że odbył się jakiś proces. Wyrok nie jest tu wynikiem starcia różnych racji - ale właśnie dlatego może być sprawiedliwy, czy raczej - dlatego może okazać się sprawiedliwy podczas wykonywania kary. Sędzia, którego funkcję (w imieniu Starego Komendanta) pełni oficer, o wyroku decyduje sam, nie przesłuchując oskarżonego, ani nawet nie zawiadamiając go, że toczy się przeciw niemu jakieś postępowanie. Proces jest tajny i dawno się już zakończył, zanim w ogóle pojawi się szansa, żeby skazany się o nim dowiedział, nie mówiąc już o wzięciu w nim udziału (z powieści Proces dowiadujemy się natomiast, że istnieje - złudna co prawda - nadzieja, iż uda się go „odroczyć”).

$\mathrm{Tu}$ - w Kolonii karnej - proces jest jednym, natychmiastowym aktem; jest decyzją. Tym samym nie ma w nim nawet pozoru relatywizmu, wykluczającego sprawiedliwość. Otóż wszelkie jawne procesy sądowe, dopuszczając oficjalnie do głosu różne punkty widzenia, tym samym uniemożliwiają sprawiedliwość. Ukazują ją bowiem - z konieczności, wbrew własnym intencjom, przez sam fakt swojej wielogłosowości - jako arbitralną wypadkową różnych, ale ostatecznie równie skończonych, równie ograniczonych perspektyw (tak jak to widać w Rashomonie Kurosawy). Nawet najsilniejsza wersja prawdziwego przebiegu wydarzeń (najbardziej prawdopodobna - uznawana przez największą liczbę najsilniejszych autorytetów) - nigdy nie jest zupełnie wiarygodna. Nie można przeskoczyć od prawdopodobieństwa do prawdy. Od negocjowania wyroku przez zewnętrzne wobec samej sprawiedliwości siły nie może być przejścia do sprawiedliwości samej, to znaczy takiej, z którą skazany mógłby się bez reszty utożsamić, na której mógłby się oprzeć w godzinie swojej śmierci. W przypadku jawnego procesu, na którym strony wygłaszają swoje zdanie, sprawiedliwość końcowa zawsze pozostaje skażona faktycznym uwarunkowaniem stron - nie jest pozaświatowa.

Ale znaczy to tylko tyle, że kafkowska maszyna z Kolonii karnej produkuje jurydyczną transcendencję; produkuje prawo jako transcendentne. Transcendencja ta, radykalnie poprzedzając prawo, jest wtórnie, mechanicznie wyprodukowanym stanem pierwotnego sprawiedliwego bezprawia. Wieczność, którą obwieszcza mit, jest stanem, w którym prawo (jeszcze i już) nie obowiązuje. Oto ogród Eden, błysk wieczności, czas kiedy sprzeczności bez obrazy koegzystują, kiedy nie ma wysiłku i nędzy.

Oczy tych ludzi - czytamy u Dostojewskiego we Śnie śmiesznego człowieka - lśniły łagodym blaskiem, i pełnią spokojnej świadomości, ale twarze te były wesołe; w słowach i głosach tych ludzi dźwieczała dziecinna radość. Gdym tylko spojrzał w ich twarze, zrozumiałem wszystko, wszystko! Była to ziemia nieskażona grzechem pierworodnym, żyli na niej ludzie, 
co nie zgrzeszyli, żyli w takim samym raju, jak - zgodnie z wierzeniami całej ludzkości - nasi grzeszni prarodzice, z tą tylko różnicą, że cała ziemia była jednym wielkim rajem ${ }^{32}$.

Chciałoby się zobaczyć ten rajski świat bezprawia w oczach żyjących ludzi! Ale widuje się go jedynie w oczach umierających, albo dokładniej - słyszy się o nim od kogoś, kto się go w oczach umierających dopatrzył i układa teraz o nim ,indywidualny mit”. Ten „błysk wieczności”, którego Michelet dopatrzył się w rewolucji francuskiej, transcendencja, wyjątek zawieszający prawo, rajski stan pierwotnego bezprawia - powstaje dopiero, mówi opowiadanie Kafki, jako wynik działania aparatu kary, w jego najbardziej nieludzkim wydaniu. To moment największego okrucieństwa, arbitralnego i bezsensownego, sytuacja, w której składa się ofiarę z człowieka. Zgadza się to skądinąd z centralną intuicją René Girarda - to przemoc skierowana przeciw niewinnej ofierze gasi kryzys społecznego ładu, a nie boska interwencja z zewnątrz, samoofiarowanie się bóstwa w rodzaju Dionizosa. Transcendencja jest wytwarzana maszynowo. Człowiek potrzebuje maszyn, żeby produkować w nich transcendencję. Jako istoty wytwarzające mity jesteśmy od samego początku cyborgami. To działanie zabójczej maszyny nadaje arbitralnej decyzji oficera - zastępcy mitycznego Starego Komendanta - wartość pozaświatowego wyjątku, ale dzieje się tak dopiero retroaktywnie. Najpierw jest arbitralna, bezsensowna, absurdalna decyzja wydana przez jakiegoś pomniejszego czynownika. „Ktoś musiał zrobić doniesienie na Józefa K.” (Kafka, 1974, s. 5).

Relacja między transcendentną decyzją a prawem odpowiada relacji między mesjaszem a mitem. Mesjasz jest bezpośredniością, mit - zapośredniczeniem. W minioną obecność mesjasza i jego ponowne przyjście można tylko wierzyć - aktualną artykulacją tej wiary jest mit, niedająca się odcyfrować arabeska, która rzekomo, w godzinie śmierci naszej, okazuje się sprawiedliwym wyrokiem. Arabeski te, rysunki zawierające podobno sentencje wyroku, sporządzone przez Starego Komendanta, dziwnie rymują się z tablicami rozrysowującymi schematy mitów, które Lévi-Strauss umieszczać chciał w swoich mitologicznych archiwach. Jako uczony w piśmie wierzył bowiem, że za pomocą liczących maszyn i kart perforowanych uda mu się odcyfrować mit - że ,więcej światła” może pomóc w odczytaniu wyroku oczami. Mylił się - mit jest czymś, w czego zrozumienie w chwili śmierci można jedynie wierzyć.

Kafka nie zostawia złudzeń co do sensu mesjanistycznej wiary w powrót Starego Komendanta (obietnica jego zmartwychwstania wyryta została przez oficera na grobie Starego Komendanta, ukrytym pod stołem w herbaciarni - mesjańska obietnica wyłonić się może najdosłowniej z każdego kąta). To wiara w absurdalną torturę jako źródło wszelkiego sensu. Jednak nie można powiedzieć, aby wiara ta była po prostu interesowna, jak myśli rzesza małodusznych niedowiarków. Oficer - kiedy sypie się jego wiara w możliwość powrotu dawnych porządków, czyli społeczeństwa zorganizowanego wokół aparatu tortur i egzekucji jako święta sprawiedliwości -

32 F. Dostojewski, Opowieści fantastyczne, tłum. M. Leśniewska, Kraków 1988, s. 138. Bohater opowiadania skaził swoją grzesznością ten rajski świat, który zobaczył w epifanicznym śnie, jaki objawił mu się w momencie samobójczej decyzji; doprowadził go do upadku. Pierwszym impulsem tego skażenia była gra, nieszczerość, imitacja, udawanie. 
okazuje się gotowym do poświęceń idealistą. W imię swojej mesjanistycznej wiary wypuszcza na wolność ostatniego skazańca, którego maszyna zabić miała w obecności podróżnego, i sam kładzie się na łożu tortur. Maszyna jednak gwałtownie przyspiesza, a w końcu psuje się i rozprzęga, wyrzucając w powietrze swoje koła zębate; kaźń oficera zamiast dwunastu godzin trwa jedynie krótką chwilę, nieszczęśnik umiera natychmiast, nie doznając oczekiwanej przemiany - w czym być może nie różni się od wszystkich wcześniejszych skazańców.

Ofiara oficera nie ma w sobie nic ze wzniosłości, jest równie bezsensowna jak porządek, w imię którego zostaje poniesiona. Można odnieść wrażenie, że w ten sposób Kafka rozprawia się z wszelkim sentymentalnym konserwatyzmem, z wszelkim łzawym wspomnieniem czasów, gdy ludzie wierzyć mogli rzekomo w sensowność swego losu, choćby najcięższego.

Kafka nie pozostawia jednak również złudzeń co do szlachetności nowego komendanta i reprezentowanej przezeń postawy „liberalnej” i „humanitarnej”. Teatr okrucieństwa, podtrzymujący wyspiarską wspólnotę, usuwa ono gdzieś na jej margines, nie likwidując go, a tylko przemieszczając, ukrywając przed oczami publiczności. Damy towarzyszące nowemu komendantowi karmią skazańców przed egzekucją cukierkami, co tylko doprowadza ich do wymiotów. Pod rządami liberalnego komendanta sfabrykowany mesjanizm oficera zastępowany jest przez kłamstwo, że żaden mesjanizm nie jest już potrzebny, kłamstwo zasłaniające tylko stare, okrutne i mordercze źródła wspólnotowości i jej mitu. Na końcu opowiadania liberalny antropolog ucieka z wyspy, odpychając od siebie pragnącego podążyć za nim więźnia, cudem uwolnionego od maszynowej śmierci, z której bliskości być może nawet nie zdawał sobie sprawy.

Kafkowska Kolonia karna jest, jak myślę, uniwersalnym modelem życia społecznego, wszelkiego życia społecznego. Życiem społecznym rządzi bowiem uwewnętrzniony mit, który w „szóstej godzinie” - w połowie drogi, na której Dante dowiedział się, że został na niego wydany wyrok - zyskuje „,skuteczność symboliczną"33, to znaczy pozwala na akceptację sensu świata, akceptację istnienia jako sensownego, akceptację własnego cierpienia i cierpienia innych jako uzasadnionego, własnej śmierci i śmierci innych jako sprawiedliwej. Mit zostaje uwewnętrzniony za sprawą aparatu tortur, za sprawą męki wplatającej ciała w porządek symboliczny. Kolonia karna

${ }^{33}$ Lévi-Strauss w Myśli nieoswojonej podkreśla co prawda, że „totemizm” wbrew tradycji, do której należy również Freud, nie jest tożsamy z systemem ofiarniczym (C. Levi-Strauss, Myśl nieoswojona, s. 296-303). „Totemizm” to, w jego ujęciu, system przeżywanych różnic w strukturze społecznej, równoległy do systemu przypisywanego naturze. Totemizm tak rozumiany zasadniczo tożsamy jest z panowaniem mitu w społeczeństwach ,zimnych”. Wydaje się, że mesjanizm, który zakłada centralny motyw ofiarniczy, pojawia się w odpowiedzi na kryzys mitu, a więc w sytuacji zaburzonego czy słabnącego porządku mitycznego - stąd postać zmarłego „Starego Komendanta” u Kafki przybiera formy mesjańskie dopiero w teoriach oficera, zwalczającego liberalizm nowego komendanta. Można jednak twierdzić, że sam porządek mityczny jest już jakiegoś rodzaju odpowiedzią na kryzys - a mianowicie kryzys, jakim jest czas, czyli niedoskonały substytut wieczności - co tylko potwierdza Lévi-Straussowska koncepcja „zimnych” społeczności, zajętych bezustannie usuwaniem szkód, jakie diachronia wyrządza synchronii. 
to parodia Golgoty - ale nie parodia wolnomyślicielska, ani nawet bluźniercza. Parodia oznacza tu raczej, jak w muzyce barokowej - wariant, równoprawną wersję mitu Ukrzyżowania, który postawić trzeba obok wariantu Ewangelii i wariantu stworzonego przez Becketta w Końcówce.

„Szósta godzina” Kafki - godzina uwewnętrznienia-musi zostać wpisana w każdy mit. W „szóstej godzinie” wieczność - której ruchomym obrazem okazuje się wtedy czas - staje się „moją sprawą”, dla której gotów jestem poświęcić mój czas (czas, który tym samym stał się mój, ponieważ go się wyrzekłem) - poświęcić moje życie. Taki właśnie - mityczny - jest rdzeń wszelkiego życia politycznego. O ile polityka jest „wielką sprawą”, o tyle jest ona mityczna, a o ile jest mityczna - o tyle odwołuje się do efektu Kafkowskiej „szóstej godziny” (być może jest on zawsze tylko imitowany, zawsze tylko wmówiony - w końcu prawdziwej przemiany doznają podobno jedynie ci, którzy umierają, pozostali mogą w to jedynie uwierzyć). A zatem tajemnicą polityki jest kafkowski aparat tortur - jest on we właściwym sensie aparatem politycznym, dlatego właśnie, że jest aparatem mitycznym, aparatem produkującym wieczność. Każde społeczeństwo próbuje - jak Syzyf - wepchąć swoje ciało społeczne - ciało wyłączonych w „szóstej godzinie” organów, które dzięki tej operacji wyłączenia przybiera postać kuli, okrągłego człowieka - na szczyt wieczności. Ale ono, to kuliste ciało, zawsze wyślizguje i upada w nijakość oraz zatracenie, w „Uneigentlichkeit": bo jest głodne, bo nie chce jeszcze umierać, bo chce trochę zarobić, albo przeciwnie, trochę roztrwonić, mieć seks, porozmawiać chwilę ze znajomymi albo też, jak nowy komendant - z ,damami”. I wtedy wszystko się rozprzęga, choć jednocześnie - w tym rozprężeniu trwa jeszcze, może nawet potężniej niż kiedykolwiek.

W związku z tym momentem „,niewłaściwości”, rozpadu porządku symbolicznego, należy jednak wyróżnić dwie odmiany aparatów politycznych, konstruując dzięki temu alternatywę - albo uzupełnienie - Lévi-Straussowskiego rozróżnienia na społeczny chłód i społeczne ciepło. Istnieją, z grubsza rzecz ujmując, aparaty produkujące politykę jako cnotę i aparaty produkujące politykę jako resentyment, cementujący tożsamości polityczne w ramach społeczeństw masowych.

Można by przypuszczać, że polityka cnoty - polityka jako głęboko uwewnętrznione przywiązanie do wielkiej sprawy, w imię której można wyłączyć własny organizm, jak Sokrates na wojnie, godzinami stojący boso na śniegu - była specjalnością heroicznych społeczności przednowoczesnych, których klasyczną reprezentantką jest Grecja. Polityka resentymentu byłaby z kolei domeną upadłej w handel i pospolitość nowoczesności. Krótko mówiąc - polityka jako cnota byłaby domeną Starego Komendanta, a polityka jako resentyment - domeną nowego komendanta. Stary Komendant jest jednak postacią mityczną, nie wiemy, czy faktycznie kiedykolwiek istniał, wiadomości o jego życiu i czynach mamy jedynie od oficera. Oficer i nowy komendant (który zresztą również nie pojawia się bezpośrednio w tekście, a jedynie w narracji oficera) są zaś sobie współcześni, to dwie strony monety, dwie postacie charakteryzujące jedną i tę samą sytuację polityczną - naszą sytuację, sytuację rozprzęgającej się i zarazem przyspieszającej maszyny politycznej.

Właściwy podział wygląda więc raczej tak: mamy $\mathrm{z}$ jednej strony politykę jako postawę jednostki, która całkowicie poświęca się sprawie - politykę oficera 
- a z drugiej strony politykę, która władzę traktuje jako biopolityczny towar, grę emocji wzbudzanych w ciałach społecznych, dla odniesienia z niej konkretnych zysków - politykę dam otaczających nowego komendanta. Te dwie odmiany polityki - politykę cnoty i politykę resentymentu - traktować należy jako dwa wytwory maszyny społecznej w stanie odśrodkowej akceleracji wywołanej zmieniającymi się formami produkcji (przy zasadniczo niezmiennym tle mitycznym). Maszyna ta była niegdyś ,zimna” w sensie Lévi-Straussa - to znaczy w istocie ponad miarę wewnętrznie rozgrzana, jak zbyt intensywnie eksploatowany kafkowski aparat tortur ale teraz rozprzęgła się i ruszyła z miejsca, w górę, w dół, w bok, na wszystkie strony - przez co w istocie stała się zarazem szybsza i bardziej schłodzona, mniej namiętna.

Już Hegel sugerował, że to rozprzężenie i odjazd aparatu władzy z terytorium symbolicznego, które niegdyś zajmował (nazywa ten teren Sittlichkeit, etycznością), może mieć w sobie coś opatrznościowego; że destrukcją dawnych form władzy rządzi chytrość przyspieszenia (która jest według niego chytrością dialektycznego rozumu, czy też harmonii między uniwersalnością a partykularnością). Aparat działa teraz sam, puszczony wolno, nie dzieli się już na panów i niewolników, każdy może wykazać się rozumnością, poddając się ogólnej zasadzie jego swobodnego funkcjonowania. W gruncie rzeczy heglowska wersja wymaga świata wciąż mocno zmityzowanego, dobrze ułożonego, choć nieco upiornego świata zdyscyplinowanego protestanckiego mieszczaństwa. Niewiele tu miejsca na rozrywkę, mało wolności i radości.

Takiego kapitalizmu - skądinąd nieludzkiego, prowokującego powstanie heroicznego i mesjanistycznego $\mathrm{z}$ ducha ruchu robotniczego - już w pierwszym świecie prawie nie ma (fabryki, z ich aparatami tortur fizycznych, przeniesiono do trzeciego świata); mamy za to system wyspecjalizowany w sprzedawaniu przyjemności. Mniej zobowiązującą, a bardziej rozrywkową, współczesną wersją chytrości przyspieszenia byłoby przekonanie, że rozprzężony aparat władzy uwolnił nas od tortury tożsamości oraz dał możliwość eksperymentalnego kształtowania życia indywidualnego i społecznego - co już jest możliwe bądź będzie możliwe niedługo, gdy uporamy się ze złogami mitu (albo resztkami gospodarki opartej na pracy fizycznej, która w wersji przemysłowej zawsze jest torturą) - a w każdym razie będziemy umieli powściągać w sobie wciąż odradzające się tendencje mityczne, to znaczy również tęsknotę za sensownością i ostatecznym celem świata (będącą przecież tylko ideologią kafkowskiego aparatu). Wydaje się jednak, że rozwój życia społecznego nie potwierdza tych nadziei, nazbyt zdawkowych i w sumie eskapistycznych jak kafkowski podróżny: za każdym „niewłaściwym” sposobem bycia czai się bowiem sposób właściwy; za każdą damą nowego komendanta czai się polityczny oficer starego komendanta.

Tym, co przytrzymywało dawny aparat władzy w miejscu, była - krótko mówiąc metafizyka polityczna, pojęta jako sztuka wytyczania granic. Pojęcia to przecież granice narzucane heroicznie materii przez arystokratyczną formę. Kluczową pośród form był rozum. Jako życie zgodne z rozumem, Arystoteles definiował zaś cnotę, do której zdolni są nieliczni (konkretnie - wolni mężczyźni, obywatele swoich państw). Metafizyka wiąże się w tym sensie z elitarnością, charakterystyczną dla gospodarki niedoboru. Aparat społeczny napędzany był siłą mięśni - co prawda nie mięśni 
arystokratów, lecz ich sług, kobiet i niewolników. To ograniczało jego szybkość. Jednak rodząca się od czasów póżnego średniowiecza gospodarka kapitalistyczna, oparta na kredycie, a więc coraz szybszych przepływach sił gospodarczych z jednego miejsca na drugie, musiała doprowadzić starą metafizykę władzy do rozpadu.

Aparat nie zniknął, ale przyspieszył. Przyspieszenie wymagało odrzucenia powstrzymujących materię form skonstruowanych rzemieślniczo - i ostatecznie odwołujących się na jakimś etapie do siły ludzkich mięśni, do pracy ludności wykluczonej z polityki, pracy „idiotów”, na rzecz „,politów”, czyli tych, którzy przywłaszczali sobie wyprodukowaną w ten sposób cnotę (korzystali ze świata społecznego, w których rzeczy miały swoje jasno zdefiniowane granice - a były nimi granice ich świata społecznego, mocno oddzielające od siebie poszczególne warstwy ludności, jasno rozgraniczające ludzi wolnych i niewolników, kobiety i mężczyzn, kapłanów, władców i wojowników). Teraz, na miejsce form chałupniczych, bricoleurskich, wstąpiły formy bardziej abstrakcyjne a mniej przywiązane do miejsca i czasu. Są to, zgodnie z Lévi-Straussowskim podziałem na bricoleurów i inżynierów - formy inżynierskie, naukowe.

Inżynier próbuje zawsze znaleźć wyjście z układu nacisków wyrażających pewien etap cywilizacji i znaleźć się poza nimi, podczas gdy blicoleur, chcąc czy nie chcąc, pozostaje wśród nich, co jest formą stwierdzenia, że ten pierwszy operuje pojęciami, ten drugi zaś znakami [...] pojęcie chce pozostać całkowicie przejrzyste w stosunku do rzeczywistości, podczas gdy znak dopuszcza, a nawet wymaga związania z tą rzeczywistością pierwiastka humanistycznego. W myśl jędrnego i trudnego do przetłumaczenia powiedzenia Peirce’a: „It adresses somebody" ${ }^{\prime 4}$.

Stosowanie pojęć zamiast znaków (to znaczy uwolnienie znaków od ich terytorium, od bycia skierowanym ku komuś i skierowanie ich ku nieskończoności) w końcu doprowadziło do powstania nowoczesnej techniki (a dokładniej - było wobec niej równoległe, technika to myślenie pojęciowe przełożone na sferę rzeczy). Istnienie aparatu władzy zostało dzięki temu w znacznej mierze uwolnione od siły ludzkich mięśni - ale nie od siły ludzkich emocji (to znaczy nie od tego, czy coś jest atrakcyjne czy nie jest - nadal siłę, jaką zlepiona jest realność reguł prawa, stanowi apetyt, przykuwający do ,pożywnej papki” codzienności bądź pozwalający zrezygnować z niej heroicznie w imię dowolnej ,wielkiej sprawy”).

W bogatych krajach kapitalistycznych władza stała się biopolitycznym towarem, sprzedawanym zgodnie z pewnymi regułami (wybory co kilka lat, kampanie wyborcze rządzące się pewnymi zasadami i gwarantujące gładkie przekazywanie władzy między poszczególnymi korporacjami politycznymi). Wojny i terroryzm są dziś potępiane szczególnie mocno głównie dlatego, że łamią prawa rynku politycznego korzystnego dla krajów pierwszego świata - podmioty terrorystyczne chcą więcej władzy niż mają pieniędzy, kradną więc władzę, piratują władzę jako towar. Tak samo zresztą traktowane są na ogół wszystkie spontaniczne, sięgające po broń strajku lub manifestacji ruchy społeczne, ruchy protestu - w związku z tym interwencje karne,

${ }^{34}$ C. Lévi-Strauss, Myśl nieoswojona, s. 35-36. 
takie jak ta w Afganistanie, Iraku, całkiem podobnie jak interwencja policji podczas ulicznego starcia itp., mają na celu tylko jedno: przywrócić wolny obrót towarami politycznymi. Ze względu jednak na słabą siłę nabywczą ukaranych podmiotów państwowych powstają w ten sposób państwa upadłe, o czym przekonuje choćby najnowszy kryzys uchodźczy.

Jednocześnie wojny i terror napędzane są przez politykę cnoty w sensie nowoczesnym, niezwiązanym z podziałem na dziedziczną arystokrację i motłoch, na ludzi wolnych i niewolników. Brak tej przepaści między wolnymi a niewolnikami - świat, w którym wszyscy są „,wolni” - sprawia, że cnota polityczna zatraca wszelkie granice, staje się wszechogarniająca, a zarazem desperacka - to znaczy świadoma, że nigdy nie zobaczy na oczy tego, w imię czego się poświęca. Ta nowoczesna polityka cnoty oznacza politykę rozpaczliwego mesjanizmu uprawianą w duchu kafkowskiego oficera, politykę absurdalnego samopoświęcenia.

Czy istnieje trzecia droga między fanatyzmem a cynizmem? W opowiadaniu Kafki jest ona co najwyżej zasygnalizowana - bardzo enigmatycznie i dwuznacznie. Mam na myśli niespodziewaną komitywę między uwolnionym $\mathrm{z}$ aparatu skazańcem a pilnującym go żołnierzem. Gdy oficer zajęty jest własnymi sprawami, skazaniec i żołnierz przekomarzają się, wyrywając sobie chustkę, jaką damy nowego komendanta obdarowały skazańca. Zwłaszcza zachowanie tego ostatniego jest dosyć infantylne, ale zarazem niezbyt przyjemne. Kafka nie ukazuje go w sentymentalnym świetle (w jakim postrzegają go zapewne damy nowego komendanta). Widać to zwłaszcza w opisie reakcji skazańca na samobójczą decyzję oficera:

[...] skazaniec zdawał się tknięty przeczuciem jakiejś wielkiej zmiany. To, co przydarzyło się jemu, spotkało teraz oficera. Może odbędzie się to aż do końca. Prawdopodobnie obcy podróżny wydał taki rozkaz. Była to więc zemsta. On sam nie wycierpiał do końca, zostanie jednak teraz aż do końca pomszczony. Szeroki, bezgłośny uśmiech pojawił się na jego twarzy i już nie znika1 ${ }^{35}$.

Ten uśmiech najwyraźniej budzi w podróżnym wstręt. Co prawda podróżny potępia sprawę, dla której oficer zdecydował się ponieść ofiarę z życia, samo to poświęcenie jest jednak w jego oczach czymś wzniosłym. Chodzi w końcu o wielką sprawę, sprawę o wymiarze ponadindywidualnym - o społeczne istnienie sprawiedliwości. Zemsta - i to zemsta za krzywdę właściwie niedoznaną, krzywdę, której skazaniec musiał się tylko domyślać - nie jest natomiast żadną wielką, uniwersalną sprawą, sama się w sobie wyczerpuje, nie prowadzi nigdzie dalej. Również koleżeństwo między skazańcem a żołnierzem nie wydaje się częścią jakiegoś powszechnego zbratania, jest pozbawione wzniosłości, przygodne, niezbyt zapewne głębokie. Podróżny może mieć wrażenie, że gdyby ich role się odwróciły - gdyby żołnierz miał być skazańcem, a skazaniem żołnierzem - nie wahaliby się robić tego, czego od nich żądano. Ponieważ jednak nikt już od nich nie żądał, aby się nawzajem prześladowali, zostali kolegami. W końcowej scenie próbują opuścić wyspę razem z podróżnym, który nie pozwala im wsiąść do swojej łodzi. Ich próby ucieczki z kolonii karnej są niezgrabne

\footnotetext{
${ }^{35}$ F. Kafka, Kolonia karna, s. 216.
} 
i nieśmiałe - „pędzili po schodach w milczeniu, gdyż nie mieli odwagi krzyczeć”36 i można odnieść wrażenie, że to opowiadanie Kafki krzyczy za nich obu.

\section{Bibliografia}

Bateson G., Steps to an Ecology of Mind. Collected Essays in Antropology, Psychiatry, Evolution, and Epistemology, Northway, NJ, London 1987.

Beckett S., Dzieła dramatyczne, thum. A. Libera, Warszawa 1988.

Busoni F., Doktor Faust. Libretto, 1925, http:/opera.stanford.edu/Busoni/DrFaust/libretto.html (Monday, 08-Dec-2003 21:50:15 PST ) [odczyt: 3.06.2017].

Dostojewski F., Opowieści fantastyczne, tłum. M. Leśniewska, Kraków 1988.

Heidegger M., 1994. Bycie i czas, tłum. B. Baran, Warszawa 1994.

Kafka F., Kolonia karna, tłum J. Kydryński [w:] tenże, Opowieści i przypowieści, różni tłumacze, Warszawa 2016.

Kafka F., Proces, tłum. B. Schulz, Warszawa 1974.

Lacan J., Mit indywidualny neurotyka albo poezja i prawda w nerwicy, thum.T Gajda, J. Kotara, J. Waga, Warszawa 2015.

Lévi-Strauss C., Antropologia strukturalna, tłum. K. Pomian, Warszawa 2000.

Lévi-Strauss C., Myśl nieoswojona, tłum. A. Zajączkowski, Warszawa 2001.

Lévi-Strauss C., Smutek tropików, tłum. A. Steinsberg, Warszawa 2008.

Schelling F.W.J., Filozofia sztuki, tłum. K. Krzemieniowa, Warszawa 1983.

36 Tamże, s. 220. 